\title{
Isolation of an Endoglucanase Gene from Bacteroides ruminicola subsp. brevis
}

\author{
By JANE R. WOODS, $\ddagger J$. FRANK HUDMAN $\dagger$ AND KEITH GREGG* \\ Institute of Biotechnology, Department of Biochemistry, Microbiology and Nutrition, \\ University of New England, Armidale 2351, Australia
}

(Received 8 February 1989; revised 2 May 1989; accepted 24 May 1989)

\begin{abstract}
A gene coding for endo-1,4- $\beta$-glucanase activity has been isolated from Bacteroides ruminicola subsp. brevis by cloning in Escherichia coli. After restriction mapping of a $6.4 \mathrm{~kb}$ insert, a $2.2 \mathrm{~kb}$ DNA fragment was sub-cloned in pUC19 to produce the enzymically active clone pJW3. Recloning of the gene fragment in the reverse orientation in pUC18 (clone pJW4) indicated that a gene promoter was present in the cloned fragment and was able to function in $E$. coli. The clone pJW4 displayed increased activity which was attributed to expression from the lac promoter of pUC18. The enzyme encoded by pJW4 was optimally active at pH 5.5-6.0, and in the temperature range $37-42{ }^{\circ} \mathrm{C}$. The preferred substrate was carboxymethylcellulose, but the enzyme displayed $50-60 \%$ of maximal activity on both acid-swollen cellulose and soluble xylan. No significant activity was detected on ball-milled filter paper or particulate xylan. Deletion experiments confirmed that both cellulase and xylanase activities were altered to a similar extent by deletion of DNA from the $3^{\prime}$ end of the gene, suggesting that both are a function of the same polypeptide product.
\end{abstract}

\section{INTRODUCTION}

Digestion of cellulose within the rumen could be made more efficient by the use of genetic engineering techniques to introduce cellulase genes into non-cellulolytic rumen bacteria (Teather, 1985; Gregg, 1989; Russell \& Wilson, 1988). The non-cellulolytic bacterium Bacteroides ruminicola has been proposed as a suitable recipient of cloned cellulase genes, because it is able to grow well under conditions of low $\mathrm{pH}$, which inhibit the growth of the major cellulolytic bacterial species (Russell \& Wilson, 1988).

We have selected an isolate of $B$. ruminicola subsp. brevis (AR20) as a suitable recipient of cloned cellulase genes. However, before attempting to introduce novel genes into this organism, it is important to know more about the genes that contribute to its natural, fibre-digesting capabilities. In addition to allowing us to define the extra genes required to achieve digestion of crystalline cellulose, this work will provide information on gene regulatory sequences that may be of use later, in regulating introduced foreign genes.

We describe here the cloning and characterization of a gene from $B$. ruminicola subsp. brevis AR20 which encodes an enzyme capable of digesting both soluble xylan and acid-swollen cellulose.

\section{METHODS}

Bacterial culture. B. ruminicola subsp. brevis strain AR20 was isolated from the ovine rumen using the roll-tube method of Hungate (1966) and was grown anaerobically at $39^{\circ} \mathrm{C}$ in the medium described by Hudman \& Glenn (1984), reduced with cysteine. $\mathrm{HCl}$ and sodium sulphide $\left(0 \cdot 25 \mathrm{~g} \mathrm{l}^{-1}\right.$ each). Species identification was based on the

\footnotetext{
† Present address: School of Business and Technology, Macarthur Institute of Higher Education, Campbelltown, NSW 2650, Australia.

$\ddagger$ Present address: Queensland Institute of Medical Research, Herston, Queensland 4006, Australia.
} 
criteria of Gram stain, morphology, motility, carbohydrate fermentation and volatile fatty acid production (Holdeman et al., 1977; Ogimoto \& Imai, 1981). All manipulations were performed anaerobically in an atmosphere of $\mathrm{CO}_{2} / \mathrm{H}_{2}(96: 4, \mathrm{v} / \mathrm{v})$.

Escherichia coli strain $\mathrm{JM} 109\left(\mathrm{~F}^{\prime}\right.$ supE44 thi traD36 proA,B $\Delta\left(\right.$ lac-proA,B) lacIqZ $\Delta M 15$ recAl relA1 $\lambda^{-}$end $A 1$ gyr $A 96$ hsdR17) was grown with shaking at $37^{\circ} \mathrm{C}$ in Luria-Bertani medium (LB medium). Plate culture was on LB medium plus $1.5 \%(\mathrm{w} / \mathrm{v})$ agar, with ampicillin $\left(50 \mu \mathrm{g} \mathrm{ml}^{-1}\right)$ added for selection of plasmid-transformed colonies.

DNA extraction. Late exponential phase cultures of $B$. ruminicola subsp. brevis AR20 (100 ml) were centrifuged at $12000 \mathrm{~g}$ (Beckman JA20 rotor) for $30 \mathrm{~min}$, washed in TE buffer (10 mM-Tris/HCl $\mathrm{pH} \mathrm{7.5,} 1 \mathrm{mM}-\mathrm{EDTA})$ and recentrifuged as before. The pellet was resuspended in $4 \mathrm{ml}$ TE buffer to which was added $8 \mathrm{mg}$ solid lysozyme (Boehringer Mannheim). After incubation at $37^{\circ} \mathrm{C}$ for $30 \mathrm{~min}, 10 \mu \mathrm{l}$ of $10 \mathrm{mg} \mathrm{ml}^{-1}$ ribonuclease (Sigma) was added together with $0.2 \mathrm{ml}$ of $10 \%$ (w/v) SDS. After a further $30 \mathrm{~min}$ at $37^{\circ} \mathrm{C}, 10 \mu \mathrm{lof} 10 \mathrm{mg} \mathrm{ml}^{-1}$ proteinase K (Boehringer-Mannheim) was added and the mixture was incubated for $1 \mathrm{~h}$ at $50^{\circ} \mathrm{C}$.

The cell lysate was extracted with an equal volume of phenol/chloroform $(1: 1, \mathrm{v} / \mathrm{v})$, followed by extractions with chloroform, and then diethyl ether, before being precipitated by the addition of 2.5 vols ethanol. The DNA was collected by centrifugation $(24000 \mathrm{~g}$, Beckman JA20 rotor) and the precipitate was washed for 10 min by gently overlaying it with $0.5 \mathrm{ml}$ of $70 \%(\mathrm{v} / \mathrm{v})$ ethanol at room temperature. After thorough draining and brief desiccation to remove ethanol, the DNA pellet was redissolved in sterile distilled water. The purity and concentration of the DNA were estimated by spectral analysis.

Plasmid DNA was extracted from $E$. coli using the alkaline-SDS method described by Maniatis et al. (1982).

Gene library construction. Genomic DNA from B. ruminicola subsp. brevis was partially digested with the restriction endonuclease $E c o R I$ (Pharmacia), using the $E c o^{*}$ activity [20 mM-Tris/ $\mathrm{HCl} \mathrm{pH} 7.9,10 \mathrm{mM}-\mathrm{MgCl}_{2}$, $1 \mathrm{mM}$-dithiothreitol (DTT) and $10 \%(\mathrm{v} / \mathrm{v})$ glycerol]. From a series of partial digests, fragments in the range $3-10 \mathrm{~kb}$ were selected by separation on a low-melting-point agarose gel $(0.8 \%$, w/v, agarose in TAE buffer: $40 \mathrm{mM}-\mathrm{Tris}$ base, $20 \mathrm{mM}$-sodium acetate, $1 \mathrm{mM}$-EDTA, adjusted to $\mathrm{pH} 8.2$ with glacial acetic acid). Size-selected DNA was extracted from gel slices by electro-elution and was ligated to EcoRI-digested arms of the bacteriophage vector $\lambda \mathrm{gtWES} . \lambda \mathrm{B}$ (Bethesda Research Laboratories) in a $10 \mu \mathrm{l}$ reaction volume containing $20 \mathrm{~mm}-\mathrm{Tris} / \mathrm{HCl} \mathrm{pH} 7 \cdot 5$, $10 \mathrm{mM}-\mathrm{MgCl}_{2}, 10 \mathrm{~mm}$-DTT, at $15^{\circ} \mathrm{C}$ for $2 \mathrm{~h}$. Ligation was confirmed by agarose gel electrophoresis and the products were packaged in $\lambda$-phage coats using the Packagene system (Promega-Biotec). Packaged, recombinant phage were infected into $E$. coli strain ED8767 (recA56 supE supF HsdS- $\mathrm{R}^{+} \mathrm{M}^{+} \mathrm{Met}^{-}$) and plated onto agar in LB medium containing $0.2 \%(\mathrm{w} / \mathrm{v})$ maltose.

Screening for xylanase and endoglucanase activity. Bacteriophage clones were screened using agar plates containing minimal medium plus $0.5 \%(w / v)$ tryptone, with either $0.2 \%(w / v)$ xylan (from oat spelts, Sigma) or $0.2 \%(\mathrm{w} / \mathrm{v})$ carboxymethylcellulose (CMC, low viscosity, Sigma). These were overlaid with $3 \mathrm{ml}$ LB medium plus $0.7 \%(\mathrm{w} / \mathrm{v})$ agar to which had been added $0.4 \mathrm{ml}$ of a suspension of $E$. coli ED8767 grown to $\mathrm{OD}_{550} 0.7$ in LB medium plus $0.2 \%(\mathrm{w} / \mathrm{v})$ maltose.

Plaques were picked using sterile toothpicks and were transferred to the xylan and CMC plates and also to a replica LB plate to act as a reservoir for screened clones. After $2 \mathrm{~d}$ incubation at $37^{\circ} \mathrm{C}$, the top-agar overlay was removed by gentle scraping from the xylan and CMC plates, which were stained by flooding for $15-30 \mathrm{~min}$ with a solution of congo-red dye (1 mg ml-1 ; Teather \& Wood, 1982). After destaining with several changes of $1 \mathrm{M}-\mathrm{NaCl}$, non-staining haloes were detectable around clones bearing a functional xylanase or endoglucanase gene.

Plasmid sub-cloning. The $B$. ruminicola subsp. brevis DNA insert, excised with EcoRI from the bacteriophage clone, was sub-cloned into the EcoRI site of the plasmid expression vector pUC19 (Yanisch-Perron et al., 1985) and transferred to $E$. coli JM109 by the simple transformation procedure of Hanahan (1985). Plasmid sub-clones were screened for enzyme activity by spotting bacterial colonies onto $\mathrm{CMC}$ and xylan plates and allowing them to grow for $24-48 \mathrm{~h}$ before washing off the bacteria and staining the plates as above.

Restriction endonuclease mapping. Digestion with restriction endonucleases was performed using the conditions specified by the manufacturer (Pharmacia). Products were analysed by electrophoresis on agarose gels $(0 \cdot 8-1 \%$, $\mathrm{w} / \mathrm{v}$, agarose in TBE buffer; Maniatis et al., 1982), against size markers consisting of $\lambda$ bacteriophage digested with HindIII.

DNA hybridization. Genomic DNA from strain AR20 was digested with EcoRI for electrophoresis on a $1 \%$ (w/v) agarose gel. The DNA was transferred by Southern blotting (Southern, 1975) to a nylon membrane (Hybond-N, Amersham) and hybridized with nick-translated DNA of the clone pJW4, using the method of Wahl et al. (1979). The radioactive probe was prepared as described previously (Ware et al., 1989).

The hybridization membrane was rinsed several times in $2 \times \operatorname{SSC}(0.3 \mathrm{M}-\mathrm{NaCl}, 0.03 \mathrm{M}$-trisodium citrate $)$ with $0.1 \%(\mathrm{w} / \mathrm{v}) \mathrm{SDS}$ at room temperature, and washed twice, for $30 \mathrm{~min}$ each, in $0.1 \times \mathrm{SSC}, 0.1 \%(\mathrm{w} / \mathrm{v}) \mathrm{SDS}$ at $65^{\circ} \mathrm{C}$, before being autoradiographed with $\mathrm{X}$-ray film (Fuji).

Preparation of cell lysates for enzyme studies. Enzymically active extracts were prepared by growing $E$. coli JM109, containing recombinant plasmids pJW3 or pJW4, to stationary phase overnight in LB medium. After centrifugation $(1000 \mathrm{~g})$ the cells were washed in 0.25 vol. TES buffer $(25 \mathrm{~mm}$-Tris/HCl $\mathrm{pH} 7.5,10 \mathrm{~mm}$-EDTA, 
$15 \%, w / v$, sucrose $)$, recentrifuged $(2000 \mathrm{~g})$ and resuspended in 0.04 vol. TE buffer. Cells were lysed by disruption with a Branson Sonifier for $4 \mathrm{~min}$ on power level $5,50 \%$ duty cycle. Triton X-100 was added to a final concentration of $0 \cdot 1 \%(\mathrm{v} / \mathrm{v})$ and the cell debris was removed by centrifugation at $27500 \mathrm{~g}$ for $10 \mathrm{~min}$.

Measurement of enzyme activity. Enzyme activity in cleared cell lysates was determined by incubating 100-250 $\mu 1$ of lysate with $500 \mu \mathrm{l}$ of substrate dissolved in phospho-citrate buffer $\left(0 \cdot 17 \mathrm{M}-\mathrm{Na}_{2} \mathrm{HPO}_{4}, 14 \mathrm{mM}\right.$-citric acid, $\left.\mathrm{pH} 7 \cdot 0\right)$. Components were mixed in an ice-bath and transferred to the incubation water-bath for the duration of the reaction, which was terminated by returning the tubes to ice. The amount of reducing sugar released during the incubation time was estimated by the colorimetric method of Nelson (1944).

Xylan was prepared as an enzyme substrate by dissolving $2 \mathrm{~g}$ in $20 \mathrm{ml} 1 \mathrm{M}-\mathrm{NaOH}$ overnight, then diluting fivefold in phospho-citrate buffer and neutralizing with $\mathrm{HCl}$. Undissolved xylan was removed by centrifugation $(12000 \mathrm{~g}$, Beckman JA20 rotor).

Phosphoric-acid-swollen cellulose was prepared as described by Wood (1971). All substrate concentrations were measured by the anthrone method described by Ashwell (1957) and standardized to $0 \cdot 34 \%(w / v)$ for determination of substrate specificity.

Protein estimation. The protein content of bacterial extracts was determined by the dye-binding method of Bradford (1976) using bovine serum albumin as a standard.

Preparation of deletion mutants from pJW4. A series of deletions were made, from the DNA at the 3 ' end of the gene, using the 'Erase-a-Base' kit (Promega-Biotec). In brief, the plasmid pJW4 was cleaved in the multiple cloning site, adjacent to the 3 ' end of the gene, with the restriction endonucleases Pst I and BamHI. Aliquots of the sample were then incubated for a series of timed increments with exonuclease III. Using this method, the exonuclease III was able to digest DNA from the BamHI terminus, into the $B$. ruminicola subsp. brevis insert, but was not able to digest the pUC vector from the $3^{\prime}$ single-stranded terminus produced by Pst $\mathrm{I}$. The single-stranded regions generated by exonuclease III digestion were hydrolysed with $\mathrm{S} 1$ nuclease, the termini were end-filled with the Klenow fragment of DNA polymerase I, and the plasmid was then recircularized by ligation.

Transformation of E. coli JM109 was followed by screening of the resultant colonies on xylan and CMC plates as described above. Plasmid mini-preparations were performed for analysis of the deletions which caused an alteration in expression of enzyme activity.

\section{RESULTS}

\section{Detection of enzymically active gene clones, and plasmid sub-cloning}

After screening 700 bacteriophage clones, a clone designated $\lambda \mathrm{JW} 1$ was selected for its ability to produce a zone of digestion on CMC plates and on xylan plates. This clone, containing a 6.4 kb DNA insert, was purified, and phage DNA was prepared for sub-cloning, using the platelysis method described by Maniatis et al. (1982).

The $6.4 \mathrm{~kb}$ insert from $\lambda \mathrm{JW} 1$ was removed intact, by cleavage with $E c o \mathrm{RI}$, and was inserted into the plasmid pUC19. The resulting recombinant plasmid (pJW1) was analysed by digestion with a series of restriction enzymes to produce the map shown in Fig. 1. After cleavage with AvaI, the 4.2 and $2.2 \mathrm{~kb}$ sub-fragments were cloned separately into pUC19 to produce the subclones pJW2 and pJW3 respectively. When tested on xylan and CMC plates, E. coli JM109(pJW2) failed to display enzyme activity, while $E$. coli JM109(pJW3) showed activity on both substrates, with larger, clearer haloes being produced on CMC.

The gene fragment was removed from pJW3, by cleavage at the EcoRI and HindIII sites in the multiple cloning site, and was inserted into pUC18 to reverse its orientation relative to the plasmid lac promoter. E. coli JM109 carrying the resulting plasmid (pJW4) produced a higher level of enzyme activity, yielding digestion haloes two to three times the diameter of those produced by cells carrying pJW3. The ability of the gene to produce active enzyme when cloned in either orientation was interpreted as an indication that the natural promoter of the gene was present in the $2.2 \mathrm{~kb}$ fragment and was functional in $E$. coli.

\section{Origin of the gene in $p J W 4$}

Hybridization of pJW4 to a Southern blot of genomic DNA of strain AR20 showed clear and specific hybridization to an EcoRI fragment of around $7 \mathrm{~kb}$ (Fig. 2). This confirmed that the DNA fragment cloned within pJW4 was derived from the rumen bacterium. The discrepancy in size between the genomic fragment identified by hybridization and the DNA insert in pJW1 


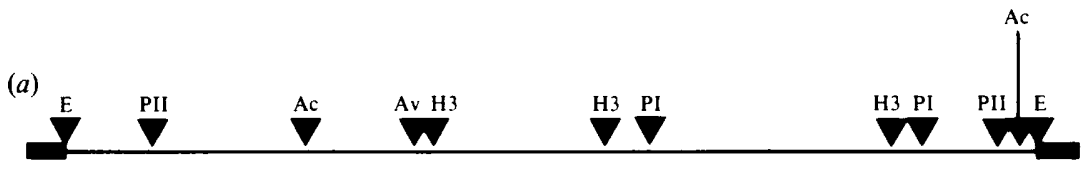

(b)

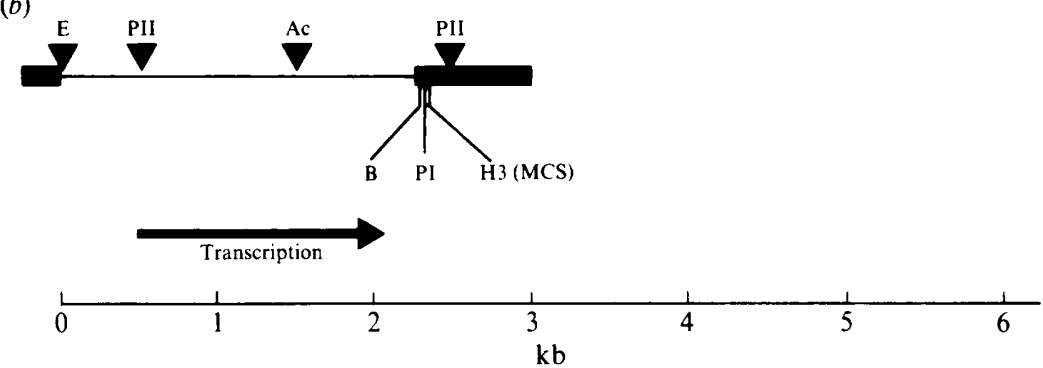

Fig. 1. Restriction map of $(a)$ the plasmid clone pJW1 and $(b)$ the plasmid sub-clone pJW4 derived from it. The broad lines represent vector DNA, the narrow lines represent DNA from $B$. ruminicola subsp. brevis, and the arrow indicates the direction of transcription of the endoglucanase gene. MCS, multiple cloning site. Restriction sites: Ac, AccI; Av, AvaI; B, BamHI; E, EcoRI; H3, HindIII; PI, PstI; PII, PvuII.

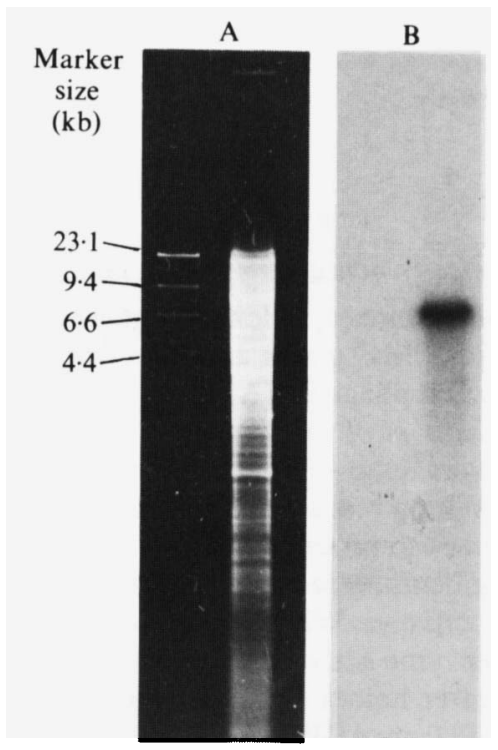

Fig. 2. A, Agarose gel showing B. ruminicola subsp. brevis genomic DNA digested with EcoRI, and B, the autoradiograph of a Southern blot of the same gel. The hybridization probe was nick-translated DNA of clone pJW4. Size markers are $\lambda$ bacteriophage DNA digested with restriction endonuclease HindIII.

suggested that one (or both) of the terminal EcoRI sites on the clone pJW1 was (were) present in the genome as an $E c o^{*}$ site(s), but became a full EcoRI recognition site(s) when ligated to the vector.

\section{Gene orientation}

It was hypothesized that the dramatic increase in enzyme activity following the reversal of gene orientation may have resulted from increased transcription of the endoglucanase gene under the control of the plasmid lac promoter. To confirm this, we made use of the ability of the 
Table 1. Effect of lac promoter induction and repression on the diameter of digestion zones produced by E. coli JM109 containing pJW3 or pJW4

A constant volume of bacterial suspension (usually $5 \mu \mathrm{l}$ ) was spotted on to CMC plates with the designated additives, followed by incubation at $37^{\circ} \mathrm{C}$ for $15 \mathrm{~h}$. Results are means of two measurements.

$\begin{array}{llc}\text { Treatment } & \text { Relative halo diameter on CMC plates } \\ \text { Control } & \text { pJW3 } & \text { JJ4 } \\ \text { Glucose } & 1 \cdot 0 & 1.0 \\ \text { IPTG } & 1 \cdot 12 & 0.87 \\ & 0.92 & 1.11\end{array}$

lac promoter to be stimulated by isopropyl $\beta$-D-thiogalactopyranoside (IPTG) and repressed by the presence of glucose. Colonies of $E$. coli JM109 containing plasmid pJW3 or pJW4 were grown on CMC or xylan plates, containing either $2 \%(\mathrm{w} / \mathrm{v})$ glucose, or $0.1 \mathrm{mg} \mathrm{IPTG} \mathrm{ml} \mathrm{m}^{-1}$. To ensure that similar numbers of bacteria were present in each colony, a specific volume (usually $5 \mu \mathrm{l})$ of an exponential-phase bacterial suspension was spotted in triplicate on each plate. Comparison of the clearing zone produced on these plates, with that produced on a control plate, made it clear that the enzyme activity produced by pJW4 was increased in the presence of IPTG and decreased in the presence of glucose (Table 1). The converse results were observed for pJW3, with increased activity in the presence of glucose and decreased activity in the presence of IPTG.

It was concluded that the $B$. ruminicola subsp. brevis gene in pJW4 occupied the same orientation as the $\beta$-galactosidase gene. Attempts to make quantitative measurements of specific enzyme activity under these conditions were complicated by the presence of large amounts of reducing sugars within the bacterial cells which were grown in the presence of high levels of glucose. However, the qualitative results obtained by measuring clearing zone diameter were sufficient to confirm activation and repression of the gene.

\section{Enzyme characterization}

Under our assay conditions, the optimum temperature for activity of the enzyme on CMC $\left(37-42^{\circ} \mathrm{C}\right)$ is similar to that within the ovine rumen $\left(39^{\circ} \mathrm{C}\right)$. However, the optimum $\mathrm{pH}$ on this substrate of 5.5-6.0 is somewhat lower than that normally observed in the rumen $(\mathrm{pH} 6 \cdot 5-7 \cdot 0)$ and lower than that observed for a number of other cloned endoglucanases (Ware et al., 1989; Taylor et al., 1987; Kawai et al., 1987; Barros \& Thompson, 1987).

Maximum enzyme activity was observed using CMC as a substrate [equivalent to $20-40 \mathrm{nmol}$ reducing sugar $\min ^{-1}$ (mg extracted protein $)^{-1}$ ]; activity on soluble xylan was $59 \%$ of maximum, and that on acid-swollen cellulose, $52 \%$. No activity was detected on the synthetic substrates methylumbelliferyl xylopyranoside, methylumbelliferyl glucopyranoside or methylumbelliferyl cellobioside.

\section{Evidence for the presence of a single gene}

Progressive deletion of DNA from the $2.2 \mathrm{~kb}$ fragment, at the $3^{\prime}$ end of the gene, resulted in the synchronous loss of both cellulase and xylanase activities. The number of nucleotides deleted from each sub-clone was determined by digestion with $P v u I I$ and measurement of the reduction in size of the $2.0 \mathrm{~kb}$ fragment that spans the deletion point (refer to Fig. 1). Deletions of approximately $120 \mathrm{bp}$ and $320 \mathrm{bp}$ resulted in an increase in endoglucanase and xylanase activity, as judged by halo diameter. Removal of a further $270 \mathrm{bp}$ resulted in the complete loss of both enzyme activities. It was concluded that both activities produced from this DNA fragment were derived from the same protein-coding sequence. 
DISCUSSION

The current model for digestion of crystalline cellulose involves the co-ordinated action of three enzymes: endoglucanase, exoglucanase and cellobiase (Enari, 1983). This hypothesis was supported by the work of Wong et al. (1988), who inserted the endoglucanase and exoglucanase genes of Cellulomonas fimi into Saccharomyces cerevisiae and were able to demonstrate the digestion of filter-paper and treated wood-chips by the altered yeast. As predicted, the digestive efficiency was enhanced by the presence of cellobiase.

Bacteroides ruminicola can use cellodextrins as a carbohydrate source (displaying a form of exoglucanase activity) and can ferment cellobiose (cellobiase activity), but cannot digest cellulose (Russell, 1988). Isolate AR20 of B. ruminicola subsp. brevis is similar in this respect (J. F. Hudman, unpublished). Therefore, the presence of an endoglucanase gene in this species (Russell \& Wilson, 1988) is intriguing, since it might be predicted that the presence of these three activities would impart the ability to digest cellulose. A possible explanation for this apparent paradox is that the exoglucanase which allows $B$. ruminicola to digest cellodextrins, and the endoglucanase detected here, may differ from those required for the degradation of crystalline cellulose in properties not yet determined. Important questions such as this may only be answered when it is possible to perform enzymic complementation tests by introducing novel genetic material into the bacterium.

Most reports dealing with cloned endoglucanases or xylanases from rumen bacteria (Taylor $e t$ al., 1987; Sipat et al., 1987; Kawai et al., 1987) have described enzymes which digest cellulose or xylan, but not both. Nevertheless, the presence of both xylanolytic and cellulolytic capabilities within cloned enzymes, from rumen bacteria, has been reported previously (Ware et al., 1989), and enzymes capable of both types of activity have been isolated from non-rumen species including Clostridium acetobutylicum (Lee et al., 1987), Clostridium thermocellum (Hall et al., 1988), and Cellulomonas fimi (Gilkes et al., 1984).

The structural similarity of substrates composed of $\beta$-1,4-linked glucopyranose residues and $\beta$-1,4-linked xylopyranose residues suggests that an endoglucanase might cleave a xylan molecule if it contained sufficiently long chains of unsubstituted residues. In the present case, the ability to digest both substrates may be due to the use of oat-spelt xylan, which has a different type and extent of substitution from the more frequently used larch-wood xylan (Aspinall, 1980). For the purpose of studying ruminant digestion, it is possible that xylan derived from monocotyledon tissue may provide more relevant results.

It is envisaged that studies of enzymes cloned from fibre-digesting bacteria may contribute to our understanding of plant cell wall digestion, and to the practical aim of making that process more efficient. For the latter purpose, however, the introduction of novel genes into a rumen bacterium could impose a metabolic burden which would selectively disadvantage the organism when reintroduced to the rumen. To prevent this, it will be necessary to ensure that introduced genes will be expressed as they would in their native organism. It is unlikely that regulatory elements which control a gene from a cellulolytic species, such as Ruminococcus albus, will function correctly when introduced into $B$. ruminicola. Therefore, to ensure that novel genes are expressed in a manner that is advantageous to the recipient bacterium, it may be necessary to attach the coding sequences of foreign cellulase genes to appropriate regulatory sequences from the host cell. The gene described here may provide control sequences suitable for this purpose.

The authors wish to thank Megan Harman for technical assistance and Cheryl Ware, Philip E. Vercoe, Dr Athol Klieve, Dr Tom Bauchop and Dr John Argyle for constructive discussion and advice in the preparation of the manuscript. This work was supported by a grant from the Australian Meat and Livestock Research and Development Corporation.

\section{REFERENCES}

ASHWELL, G. (1957). Colorimetric analysis of sugars. Methods in Enzymology 3, 73-105.

AspinalL, G. O. (1980). Chemistry of cell wall polysaccharides. In The Biochemistry of Plants, vol. 3,
Carbohydrates: Structure and Function, pp. 473-500. Edited by J. Preiss. Sydney, Australia: Academic Press.

Barros, M. E. C. \& Thompson, K. A. (1987). Cloning 
and expression in $E$. coli of a cellulase gene from Ruminococcus flavefaciens. Journal of Bacteriology 169, 1760-1762.

BRADFORD, M. M. (1976). A rapid and sensitive method for the quantitation of microgram quantities of protein utilizing the principle of protein-dye binding. Analytical Biochemistry 72, 248-254.

ENARI, T. M. (1983). Microbial cellulases. In Microbial Enzymes and Biotechnology, pp. 183-223. Edited by W. M. Fogarty. London: Applied Science Publishers.

Gilkes, N. R., Langsford, M. L., Kilburn, D. C., Miller, R. C., JR \& Warren, R. A. J. (1984). Mode of action and substrate specificities of cellulases from cloned bacterial genes. Journal of Biological Chemistry 259, 10455-10459.

GREGG, K. (1989). Genetic engineering of rumen bacteria. In The Biology of Wool and Hair, pp. 417 424. Edited by G. E. Rogers, P. J. Reis, K. A. Ward \& R. C. Marshall. London: Chapman \& Hall.

Hall, J., Hazlewood, G. P., Barker, P. J. \& GilberT, H. J. (1988). Conserved reiterated domains in Clostridium thermocellum endoglucanases are not essential for catalytic activity. Gene 69, 29-38.

HaNAHAN, D. (1985). Techniques for transformation of E. coli. In DNA Cloning : a Practical Approach, vol. 1, pp. 109-135. Edited by D. M. Glover. Oxford: IRL Press.

Hobson, P. N. \& Wallace, R. J. (1982). Microbial ecology and activities in the rumen. CRC Critical Reviews in Microbiology 9, 165-225 (part 1) and 253320 (part 2).

Holdeman, L. V., Cato, E. P. \& Moore, W. E. C. (1977). Anaerobe Laboratory Manual, 4th edn. Blacksburg, Virginia: Virginia Polytechnic Institute and State University.

Hudman, J. F. \& GlenN, A. R. (1984). Selenite uptake and incorporation by Selenomonas ruminantium. Archives of Microbiology 140, 252-256.

Hungate, R. E. (1966). The Rumen and Its Microbes. New York: Academic Press.

Kawai, S., Honda, H., Tanase, T., Taya, M., Iijima, S. \& Kobayashi, T. (1987). Molecular cloning of Ruminococcus albus cellulase gene. Agricultural and Biological Chemistry 51, 59-63.

Lee, S. F., Forsberg, C. W. \& Rattray, J. B. (1987). Purification and characterization of two endoxylanases from Clostridium acetobutylicum ATCC 824. Applied and Environmental Microbiology 53, 644-650.

Maniatis, T., Fritsch, E. F. \& Sambrook, J. (1982). Molecular Cloning: a Laboratory Manual. Cold Spring Harbor, NY: Cold Spring Harbor Laboratory.

Nelson, N. (1944). A photometric adaptation of the Somogyi method for the determination of glucose. Journal of Biological Chemistry 153, 375-380.
Ogimoto, K. \& Imai, S. (1981). Atlas of Rumen Microbiology. Tokyo, Japan: Japan Scientific Societies Press.

Russell, J. B. (1988). Ecology of rumen microorganisms: energy use. In Aspects of Digestive Physiology in Ruminants, pp. 74-98. Edited by A. Dobson \& M. Dobson. Ithaca, NY: Comstock Publishing Associates/Cornell University Press.

Russell, J. B. \& Wilson, D. B. (1988). Potential opportunities and problems for genetically altered rumen microorganisms. Journal of Nutrition 118, 271-279.

Sipat, A., Taylor, K. A., Lo, R. Y. C., Forsberg, C. W. \& KRell, P. J. (1987). Molecular cloning of a xylanase gene from Bacteroides succinogenes and its expression in Escherichia coli. Applied and Environmental Microbiology 53, 477-481.

SOUTHERN, E. (1975). Detection of specific sequences among DNA fragments separated by gel electrophoresis. Journal of Molecular Biology 98, 503-517.

TAYlor, K. A., Crosby, B., McGavin, M., ForsberG, C. W. \& Thomas, D. Y. (1987). Characteristics of an endoglucanase encoded by a cel gene from Bacteroides succinogenes expressed in E. coli. Applied and Environmental Microbiology 53, 41-46.

TEATHER, R. M. (1985). Application of gene manipulation to rumen microflora. Canadian Journal of Animal Sciences 65, 563-574.

Teather, R. M. \& Wood, P. J. (1982). Use of congo red-polysaccharide interactions in enumeration and characterization of cellulolytic bacteria from the bovine rumen. Applied and Environmental Microbiology 43, 777-780.

Wahl, G. M., Stern, M. \& Stark, G. R. (1979). Efficient transfer of large DNA fragments from agarose gels to diazobenzyloxymethal paper and rapid hybridization by using dextran sulfate. Proceedings of the National Academy of Sciences of the United States of America 76, 3683-3687.

Ware, C. E., Bauchop, T. \& GregG, K. (1989). Isolation and comparison of endoglucanase genes from two strains of Ruminococcus albus. Journal of General Microbiology 135, 921-930.

Wong, W. K. R., CUrry, C., Parekh, R. S., Parekh, S. R., Wayman, M., Davies, R. W., Kilburn, D. G. \& SKIPPER, N. (1988). Wood hydrolysis by Cellulomonas fimi endoglucanase and exoglucanase coexpressed as secreted enzymes in Saccharomyces cerevisiae. Bio/Technology 6, 713-719.

WooD, T. M. (1971). The cellulases of Fusarium solani. Biochemical Journal 121, 353-362.

Yanisch-Perron, C., Vieira, J. \& Messing, J. (1985). Improved M13 phage cloning vectors and host strains: nucleotide sequences of the $\mathrm{M} 13 \mathrm{mp} 18$ and pUC19 vectors. Gene 33, 103-119. 